\title{
Substance $P$ and NK-1R expression in oral precancerous epithelium
}

\author{
M.A. GONZALEZ-MOLES ${ }^{1}$, S. BRENER ${ }^{2}$, I. RUIZ-AVILA ${ }^{3}$, \\ J.A. GIL-MONTOYA ${ }^{1}$, D. TOSTES ${ }^{2}$, M. BRAVO ${ }^{4}$ and F. ESTEBAN ${ }^{5}$
}

\begin{abstract}
${ }^{1}$ Oral Medicine Department, School of Dentistry, University of Granada, Paseo de Cartuja s/n, 18071 Granada, Spain; ${ }^{2}$ Oral Medicine Department, School of Dentistry, University of São Paulo, Alameda Doutor Octavio Pinheiro Brisolla 9-75, Bauru, CEP 17012-901, São Paulo, Brasil; ${ }^{3}$ Pathology Department, Jaen Central Hospital, Jaen, Avda Ejercito Español 10, 23007 Jaen; ${ }^{4}$ Preventive and Public Health in Dentistry Department, University of Granada, Paseo de Cartuja s/n, 18071 Granada, ${ }^{5}$ Department of Otorhinolaryngology, Virgen del Rocio University Hospital, Sevilla,
\end{abstract} Avda Manuel Siurot s/n, 41013 Sevilla, Spain

Received February 12, 2009; Accepted May 23, 2009

DOI: 10.3892/or_00000571

\begin{abstract}
The objectives of this study were to investigate the presence and distribution of substance $\mathrm{P}$ and neurokinin 1 receptor in oral premalignant epithelium and their relation with the presence of dysplasia, and to analyze whether the expression of substance $\mathrm{P}$ can be considered an early oncogenic event in oral carcinogenesis. Substance P and neurokinin 1 receptor expression was immunohistochemically studied in 83 oral carcinomas and adjacent nontumor epithelia. The presence and degree of epithelial dysplasia was assessed according to WHO criteria. The nuclear, cytoplasmic, and membrane expression of substance $\mathrm{P}$ and the cytoplasmic and membrane expression of neurokinin 1 receptor were assessed in tumor and adjacent non-tumor epithelium. Nuclear and cytoplasmic expression of substance $\mathrm{P}$ in non-tumor epithelium was significantly associated with the presence of epithelial dysplasia $(\mathrm{p}<0.001)$ and carcinoma in situ ( $\mathrm{p}=0.021)$. Nuclear, cytoplasmic, and membrane expressions of substance $\mathrm{P}$ in non-tumor epithelium were significantly $(\mathrm{p}<0.001)$ associated with its expression in the corresponding tumor. These findings suggest that substance $\mathrm{P}$ plays a role in early oral carcinogenesis by promoting the proliferation and growth of premalignant fields.
\end{abstract}

\section{Introduction}

The development of oral carcinoma is a multistep process involving multiple oncogenic alterations (1). Some of these

Correspondence to: Dr Miguel Angel González-Moles, Facultad de Odontología, Paseo de Cartuja s/n, 18071 Granada, Spain E-mail:magonzal@ugr.es

Key words: substance P, NK-1 receptor, precancerous epithelium, oral cancer are considered early oncogenic events, including changes in chromosomal regions $3 \mathrm{p}, 9 \mathrm{p}$, and $17 \mathrm{p}(2,3)$. Although tumor suppressor genes and putative oncogenes in these regions have yet to be identified (4), these chromosomal areas are known to be carriers of important cell-cycle and apoptosis-regulating genes. Thus, CDKN2A locus, which encodes for p16 protein, is located in chromosome 9p21, and p53 gene is in chromosome 17p13 (5). These early oncogenic events have been demonstrated in precancerous fields (4) and endow cells with an increased proliferation rate that affords them a growth advantage over epithelial cells of the adjacent healthy oral mucosa. This phenomenon considerably increases the number of target cells in which new oncogenic events can take place, which would ultimately lead to the development of one or more invasive carcinomas (4).

There has been increasing interest over the past few years in the role of substance P (SP) in the development and progression of certain types of tumor (6). SP, an undecapeptide of the tachykinin peptide family, regulates multiple biological functions by binding to the NK-1 receptor (NK-1R), including cardiovascular and respiratory mechanisms, sensory perception, and response to stress, among others (7-10). However, one of its most important functions is related to its action as a potent mitogen on some precancerous epithelial lesions and some human cancer cell lines, e.g., glioma, retinoblastoma, neuroblastoma, melanoma, and laryngeal carcinoma as previously reported by our group (6,11-17). These observations suggest that SP may play a role in cancer development by acting as a promoter of cell growth. No information has been published to date on SP expression in oral cancers or in the precancerous epithelia that frequently accompany them. Given that an important characteristic of these epithelia is their increased proliferation rate, the present study was designed to investigate the presence and distribution of SP and NK-1R in oral premalignant epithelium and their relationship with the presence of dysplasia, and to determine whether SP expression can be considered an early oncogenic event in oral carcinogenesis. 


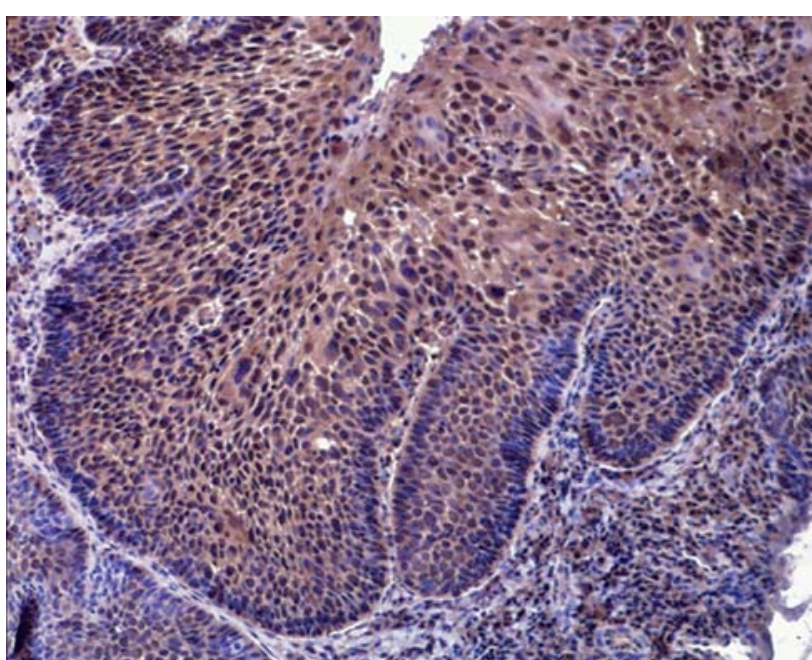

Figure 1. Cytoplasmic and nuclear expression of SP in non-tumor epithelium adjacent to an invasive carcinoma with severe dysplasia/carcinoma in situ (immunohistochemical technique; x20).

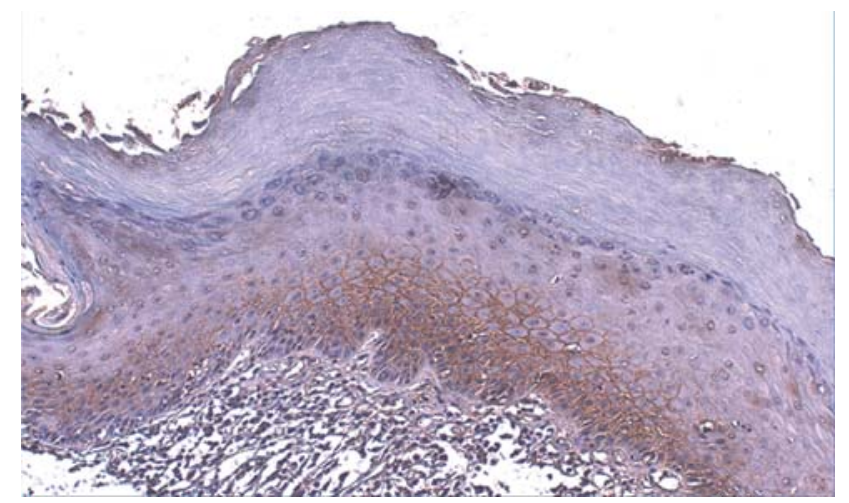

Figure 2. Cytoplasmic and membrane expression of NK-1R in nontumor epithelium that is adjacent to an invasive carcinoma and shows squamous hyperplasia (immunohistochemical technique; x20).

\section{Patients and methods}

Patients. We studied 83 oral squamous cell carcinomas (OSCC) that had non-tumor epithelium associated with the invasive tumor. They derived from 67 patients aged between 27 and 91 years $(60.0 \pm 11.6)$ under treatment at the Jaen Hospital Complex (Spain); 51 patients $(76.1 \%)$ were male, and $38(73 \%)$ were smokers or ex-smokers. The hospital medical records of the patients were reviewed, and data were gathered on the clinicopathological characteristics of lesions. Hematoxylin and eosin staining was used to assess the histological grade of non-tumor epithelium adjacent to the OSCC according to WHO classifications (18): squamous hyperplasia, mild dysplasia, moderate dysplasia, severe dysplasia, or carcinoma in situ. WHO assessment criteria (18) were used for the diagnosis of epithelial dysplasia. Clinicopathological variables were considered missing when they were not included in the clinical records or, in the histological grade assessment of non-tumor epithelium, when there was inadequate amount of non-tumor epithelium for a reliable assessment of dysplasia.
Immunohistochemistry. For the immunohistochemical staining, 4- $\mu \mathrm{m}$ sections were cut from paraffin blocks of the tissue samples. The peroxidase-antiperoxidase technique was used, performing immunohistochemical analysis by means of the avidin-biotin method. Slides were deparaffinized in xylene, hydrated, and incubated with $0.5 \%(\mathrm{v} / \mathrm{v}) \mathrm{H}_{2} \mathrm{O}_{2}$ in methanol for 20 min to block endogenous peroxidase activity. Slides were then washed with Tris-buffered saline and heated for $15 \mathrm{~min}$ at $100^{\circ} \mathrm{C}$ in $10 \mathrm{mM}$ sodium citrate buffer ( $\mathrm{pH} 6.0$ ) for antigen retrieval. Non-specific binding was blocked by incubation with $1 \%$ BSA for $1 \mathrm{~h}$. Sections were incubated with primary antibodies overnight at $4^{\circ} \mathrm{C}$. The color was developed using diaminobenzidine as chromogen. Slides were extensively washed with TBS after each step. Finally, they were counterstained with Mayer's hematoxylin and mounted with DPX mountant. For the negative control, the primary antibody was replaced with phosphate-buffered saline. For the positive control, tissue was used from a laryngeal carcinoma known to intensively express the proteins under study. The expression of this protein in peripheral nerves was considered as positive internal control. Anti-SP (Sigma, St. Louis, MO), and anti-NK-1R (Sigma-Aldrich, Madrid, Spain) primary antibodies were used, evaluating SP expression in nucleus, cytoplasm, and membrane (Fig. 1) and NK-1R expression in cytoplasm and membrane (Fig. 2). Markers were considered positive when the color brown appeared in some of these localizations. Expression of these markers in premalignant epithelium was assessed in four randomized high-power fields (x40), dividing the epithelium thickness into thirds. In each of the fields analyzed and for each epithelial compartment considered, the total cell number and the number of positive cells were counted, obtaining a mean expression percentage for each case in each epithelial compartment. The markers were also assessed in the tumor tissue accompanying the precancerous epithelium. Counts were performed in four randomized high-power fields (x40) to obtain the mean expression percentage for each tumor.

Cases were assigned to one of the following categories: $0 \%$ positive cells $(-), 1-25 \%$ positive cells $(+), 26-50 \%$ positive cells $(++), 51-75 \%$ positive cells $(+++)$, or $>75 \%$ positive cells $(++++)$. The histological and immunohistochemical analyses were always performed by the same examiner (MAGM), who was blinded to the clinical stage, treatment, and course of the disease. Some cases of adjacent epithelium or tumor were considered non-assessable when the immunohistochemical technique did not yield reliable results despite repetition.

Statistical analysis. Statistical methods are reported in Table footnotes. To calculate means and standard deviations of SP and NK-1R, we considered the mean value of each interval: negative $(0 \%)$, mean of $0 \% ;+(1 \%-25 \%), 13 \%$; $++(26 \%-50 \%) ; 38 \% ;+++(51 \%-75 \%), 63 \%$; and ++++ (76\%-100\%), mean of $88 \%$. SPSS-Windows v.15.0 (SPSS Inc., Chicago, IL) was used for the descriptive analysis. For the calculation of p-values, we applied SUDAAN v.7.0 (Research Triangle Institute, RTP, NC), using WR (withreplacement) design to account for clustering (multiple oral cancers in patients). 
Table I. Clinicopathological parameters of tumors $(n=83) .^{a}$

\begin{tabular}{|c|c|}
\hline Variable & $\mathrm{n}(\%)$ \\
\hline \multicolumn{2}{|l|}{ Localization } \\
\hline Tongue & $45(54.2)$ \\
\hline Mouth floor & $13(15.7)$ \\
\hline Floor + tongue & $10(12.0)$ \\
\hline Trigone & $4(4.8)$ \\
\hline Other ${ }^{b}$ & $11(3.3)$ \\
\hline \multicolumn{2}{|l|}{ Clinical presentation } \\
\hline Ulcer & $33(46.5)$ \\
\hline Tumor & $22(31.0)$ \\
\hline Leukoplakia + tumor & $8(11.3)$ \\
\hline Other & $8(11.3)$ \\
\hline Missing & 12 \\
\hline \multicolumn{2}{|l|}{ Size } \\
\hline $\mathrm{T} 1$ & $25(32.5)$ \\
\hline $\mathrm{T} 2$ & $29(37.7)$ \\
\hline $\mathrm{T} 3$ & $10(13.0)$ \\
\hline $\mathrm{T} 4$ & $13(16.9)$ \\
\hline Missing & 6 \\
\hline \multicolumn{2}{|l|}{ Adenopathies } \\
\hline N0 & $49(63.6)$ \\
\hline N1 & $19(24.7)$ \\
\hline $\mathrm{N} 2 \mathrm{a}$ & $5(6.5)$ \\
\hline $\mathrm{N} 2 \mathrm{~b}$ & $2(2.6)$ \\
\hline $\mathrm{N} 2 \mathrm{c}$ & $1(1.3)$ \\
\hline N3 & $0(0.0)$ \\
\hline NX & $1(1.3)$ \\
\hline Missing & 6 \\
\hline \multicolumn{2}{|l|}{ Metastasis } \\
\hline M0 & $61(79.2)$ \\
\hline M1 & $1(1.3)$ \\
\hline MX & $15(19.5)$ \\
\hline Missing & 6 \\
\hline \multicolumn{2}{|l|}{ Stage } \\
\hline I & $20(26.0)$ \\
\hline II & $19(24.7)$ \\
\hline III & $19(24.7)$ \\
\hline IVa & $18(23.4)$ \\
\hline $\mathrm{IVb}$ & $0(0.0)$ \\
\hline IVc & $1(1.3)$ \\
\hline Missing & 6 \\
\hline \multicolumn{2}{|l|}{ Degree of differentiation } \\
\hline $\mathrm{BD}$ & $31(41.9)$ \\
\hline MD & $26(35.1)$ \\
\hline PD & $17(23.0)$ \\
\hline Missing & 9 \\
\hline
\end{tabular}

${ }^{\mathrm{a} C}$ Corresponding to 67 patients. ${ }^{\mathrm{b}}$ Oral mucosa + trigone $(\mathrm{n}=1)$, buccal mucosa $(n=3)$, soft palate + oral mucosa $(n=2)$, lower lip $(n=2)$, and gingiva $(n=3)$. ${ }^{c}$ Lichen planus + ulcer $(n=2)$, Erythroleukoplakia $(n=3)$ and Leukoplakia + ulcer $(n=3)$.

\section{Results}

Table I lists the clinicopathological data of the tumors. The most frequent localization was the tongue (45 cases; $54.2 \%$ ), and the most frequent clinical presentation was ulceration of malignant appearance (33 cases; 46.5\%). In this series, 25 cases $(32.5 \%)$ were T1, 29 cases $(37.7 \%) \mathrm{T} 2,49$ cases $(63.6 \%)$ N0, and 61 cases (79.2\%) M0. Table II includes data on the multiple tumors in 10 of the patients $(15 \%)$. Regarding the histological grade of non-tumor epithelium adjacent to the OSCC, 20 epithelia (28.2\%) had squamous hyperplasia, 11 epithelia (15.5\%) mild epithelial dysplasia, 24 (33.8\%) moderate dysplasia, and 16 (22.5\%) severe dysplasia/carcinoma in situ. In the remaining 12 cases, the examiner did not report the presence or severity of epithelial dysplasia. Table III shows the percentage expression of SP and NK-1R in non-tumor epithelia adjacent to OSCC and Table IV the percentage expression of SP and NK-1R in the tumors. Table $\mathrm{V}$ shows the expression of $\mathrm{SP}$ and NK-1R in adjacent non-tumor epithelia as a function of the presence of severe epithelial dysplasia/carcinoma in situ. A significant association was found between SP expression in nucleus/cytoplasm at all epithelial levels studied and the presence of severe epithelial dysplasia carcinoma in situ. Table VI shows the correlation between SP expression in adjacent non-tumor epithelium and in the invasive tumor. A significant direct correlation was found between tumor and epithelial expression of SP, regardless of the presence or not of dysplasia.

\section{Discussion}

This study revealed an elevated SP expression and a less marked expression of NK-1R in the membrane, cytoplasm and nucleus of epithelial cells in non-tumor epithelia adjacent to invasive carcinomas, providing the first demonstration of $\mathrm{SP}$ and NK-1R expression in oral precancerous epithelium.

$\mathrm{SP}$ can activate members of the mitogen-activated protein kinase (MAPK) cascade, including extracellular signalregulated kinases 1 and 2 (ERK 1/2), which translocate to the nucleus to induce cell proliferation and protect the cell from apoptosis (19). In vitro studies have revealed the importance of MAPK activation in the proliferative activity of keratinocytes in squamous epithelium. Thus, epithelial stem cells in suspension acquired characteristics of transient amplifying cells, which developed terminal differentiation after two or three proliferative cycles (20). However, some situations involving activation of the MAPK cascade (e.g., interaction of keratinocytes in suspension with $B 1$ integrin or introduction of active MAPK mutant into culture) promote persistence of a hyperproliferative state of stem cells in which they do not develop terminal differentiation (21), and this state is characteristic of precancerous epithelium (2). Moreover, SP can also induce cell proliferation via transactivation of the epidermal growth factor receptor (EGFR) (6). Hence, our results suggest that SP may play an oncogenic role by stimulating the cell proliferation of oral precancerous epithelium. The less marked expression of NK-1R suggests that SP proliferation pathways in oral precancerous epithelium may, at least in part, differ from those mediated by receptor NK-1. Therefore, the nuclear expression of SP may also 
Table II. Clinicopathological characteristics of patients with multiple tumors ( $\mathrm{n}=10$ patients and 27 tumors).

\begin{tabular}{|c|c|c|c|c|c|c|c|c|}
\hline Patient & Age $^{a}$ & Gender & Tumor & Localization & $\mathrm{T}$ & $\mathrm{N}$ & M & Grade \\
\hline \multirow[t]{2}{*}{1} & 54 & M & 1 & $\mathrm{R}$ Mobile tongue & $\mathrm{T} 1$ & N1 & $\mathrm{Mx}$ & WD \\
\hline & & & 2 & $\mathrm{R}$ Base of tongue & $\mathrm{T} 1$ & N1 & $\mathrm{Mx}$ & WD \\
\hline \multirow[t]{2}{*}{2} & 45 & M & 1 & $\mathrm{R}$ Tongue + Floor & $\mathrm{T} 4$ & N1 & M0 & MD \\
\hline & & & 2 & L Tongue + Floor & $\mathrm{T} 4$ & N1 & M0 & MD \\
\hline \multirow[t]{2}{*}{3} & 61 & M & 1 & R Mouth floor & $\mathrm{T} 4$ & No & M0 & WD \\
\hline & & & 2 & L Mouth floor & $\mathrm{T} 4$ & No & M0 & MD \\
\hline \multirow[t]{2}{*}{4} & 49 & M & 1 & L Base of tongue & $\mathrm{T} 1$ & N1 & $\mathrm{Mx}$ & MD \\
\hline & & & 2 & L Mobile tongue & $\mathrm{T} 1$ & N1 & Mx & MD \\
\hline \multirow[t]{2}{*}{5} & 62 & $\mathrm{~F}$ & 1 & L Mobile tongue & $\mathrm{T} 2$ & No & M0 & MD \\
\hline & & & 2 & Anterior mouth floor & $\mathrm{T} 2$ & No & M0 & MD \\
\hline \multirow[t]{3}{*}{6} & 70 & $\mathrm{~F}$ & 1 & L Base of tongue & $\mathrm{T} 2$ & No & M0 & PD \\
\hline & & & 2 & L Mobile tongue & $\mathrm{T} 2$ & No & M0 & MD \\
\hline & & & 3 & $\mathrm{R}$ Mobile tongue & $\mathrm{T} 2$ & No & M0 & MD \\
\hline \multirow[t]{3}{*}{7} & 68 & M & 1 & L Mobile tongue & $\mathrm{T} 2$ & N1 & M0 & MD \\
\hline & & & 2 & L Base of tongue & $\mathrm{T} 2$ & N1 & M0 & MD \\
\hline & & & 3 & Anterior mouth floor & $\mathrm{T} 2$ & N1 & M0 & MD \\
\hline \multirow[t]{3}{*}{8} & 52 & $\mathrm{~F}$ & 1 & L Mobile tongue & $\mathrm{T} 4$ & No & M0 & WD \\
\hline & & & 2 & $\mathrm{R}$ Base of tongue & $\mathrm{T} 4$ & No & M0 & WD \\
\hline & & & 3 & R Oral mucosa & $\mathrm{T} 3$ & No & M0 & WD \\
\hline \multirow[t]{3}{*}{9} & 49 & M & 1 & L Anterior mouth floor & $\mathrm{T} 1$ & No & M0 & MD \\
\hline & & & 2 & $\mathrm{R}$ Anterior mouth floor & $\mathrm{T} 1$ & No & M0 & MD \\
\hline & & & 3 & $\mathrm{R}$ Base of tongue & $\mathrm{T} 1$ & No & M0 & WD \\
\hline \multirow[t]{5}{*}{10} & 63 & $\mathrm{~F}$ & 1 & Anterior lower gingiva & $\mathrm{T} 3$ & No & M0 & MD \\
\hline & & & 2 & $\mathrm{R}$ Lower gingiva & $\mathrm{T} 2$ & No & M0 & WD \\
\hline & & & 3 & Lower lip & $\mathrm{T} 2$ & No & M0 & WD \\
\hline & & & 4 & $\mathrm{R}$ Trigone & $\mathrm{T} 2$ & No & M0 & WD \\
\hline & & & 5 & L Upper gingiva & $\mathrm{T} 1$ & No & M0 & WD \\
\hline
\end{tabular}

${ }^{\mathrm{a}}$ Mean $\pm \mathrm{sd}=57.3 \pm 8.6$ years. R, right; L, left; WD, well differentiated; MD, moderately differentiated; PD, poorly differentiated.

indicate the presence of nuclear receptors for this protein other than NK-1R, as reported for other proteins (e.g., melatonin, that has nuclear and membrane receptors) (22), which may be responsible for the proliferative stimulus. Our findings also suggest that SP may contribute to the growth of precancerous fields in the same way as early oncogenic alterations of these fields, affecting chromosomal loci $(3 p, 9 p, 17 p)$ that host cell cycle-regulating genes (2). Loss of the corresponding functions allows field cells to acquire proliferative advantages and progressively replace normal oral mucosa.

Unlike the molecular identification of precancerous fields, it would be feasible to routinely test for SP overexpression as a potential indicator of precancerous fields, although prospective studies are required to test this hypothesis. The present results also demonstrate a significant association between SP expression and the presence of severe epithelial dysplasia/carcinoma in situ, which indicates that
SP-mediated cell mechanisms operate at stages close to malignant transformation. Furthermore, there was a significant and direct correlation between the expression of SP in adjacent non-tumor epithelium and the expression of SP in the OSCC, suggesting that cell clones with an early proliferative stimulation maintain this SP-mediated advantage even after acquiring the capacity to invade. In this context, a previous report by our group on SP and oral lichen planus (17) proposed an SP diffusion pathway of lymphocyte origin via the corium towards membrane, cytoplasm, and nucleus of epithelial cells, where it exerts its proliferation-promoting action. Therefore, the immunological surveillance system developed by lymphocytes adjacent to a precancerous and cancerous epithelium may represent a source of SP that is to some extent responsible for tumor progression and growth. This would be another example of how the inflammatory infiltrate itself may constitute a risk factor for tumor development (23). 
Table III. Percentage expression of SP and NK-1R in non-tumor epithelia adjacent to oral tumors $(n=83) .{ }^{a}$

\begin{tabular}{|c|c|c|c|c|c|c|}
\hline & \multicolumn{5}{|c|}{ Expression (\%) } & \multirow[b]{2}{*}{ mean $\pm \mathrm{sd}^{\mathrm{b}}$} \\
\hline & $\begin{array}{c}\text { Negative } \\
(0 \%)\end{array}$ & $\begin{array}{c}+ \\
(1-25 \%)\end{array}$ & $\begin{array}{c}++ \\
(26-50 \%)\end{array}$ & $\begin{array}{c}+++ \\
(51-75 \%)\end{array}$ & $\begin{array}{c}++++ \\
(76-100 \%)\end{array}$ & \\
\hline \multicolumn{7}{|c|}{ Expression of SP $(n=69)$} \\
\hline \multicolumn{7}{|c|}{ Nucleus } \\
\hline 1/3 lower & 73.9 & 1.4 & 10.1 & 13.0 & 1.4 & $13.5 \pm 24.6$ \\
\hline $1 / 3$ medium & 69.6 & 2.9 & 11.6 & 14.5 & 1.4 & $15.2 \pm 25.3$ \\
\hline $1 / 3$ upper & 92.8 & 1.4 & 2.9 & 2.9 & 0.0 & $3.1 \pm 12.3$ \\
\hline Maximum $^{\mathrm{c}}$ & 68.1 & 2.9 & 13.0 & 14.5 & 1.4 & $15.7 \pm 25.3$ \\
\hline \multicolumn{7}{|l|}{ Cytoplasm } \\
\hline 1/3 lower & 52.2 & 7.2 & 7.2 & 29.0 & 4.3 & $25.8 \pm 30.9$ \\
\hline $1 / 3$ medium & 55.1 & 5.8 & 4.3 & 30.4 & 4.3 & $25.4 \pm 31.4$ \\
\hline 1/3 upper & 94.2 & 0.0 & 1.4 & 4.3 & 0.0 & $3.3 \pm 13.6$ \\
\hline Maximum & 50.7 & 7.2 & 5.8 & 31.9 & 4.3 & $27.1 \pm 31.3$ \\
\hline \multicolumn{7}{|l|}{ Membrane } \\
\hline 1/3 lower & 49.3 & 7.2 & 7.2 & 36.2 & 0.0 & $26.5 \pm 29.4$ \\
\hline $1 / 3$ medium & 34.8 & 15.9 & 11.6 & 37.7 & 0.0 & $30.2 \pm 28.1$ \\
\hline 1/3 upper & 94.2 & 0.0 & 0.0 & 5.8 & 0.0 & $3.6 \pm 14.8$ \\
\hline Maximum & 33.3 & 15.9 & 11.6 & 39.1 & 0.0 & $31.1 \pm 28.1$ \\
\hline \multicolumn{7}{|c|}{ Expression of NK-1R (n=68) } \\
\hline \multicolumn{7}{|c|}{ Cytoplasm } \\
\hline $1 / 3$ lower & 85.3 & 2.9 & 7.4 & 4.4 & 0.0 & $6.0 \pm 15.9$ \\
\hline $1 / 3$ medium & 77.9 & 7.4 & 8.8 & 5.9 & 0.0 & $8.0 \pm 17.7$ \\
\hline $1 / 3$ upper & 98.5 & 1.5 & 0.0 & 0.0 & 0.0 & $0.2 \pm 1.6$ \\
\hline Maximum & 77.9 & 7.4 & 8.8 & 5.9 & 0.0 & $8.0 \pm 17.7$ \\
\hline \multicolumn{7}{|l|}{ Membrane } \\
\hline 1/3 lower & 89.7 & 4.4 & 4.4 & 1.5 & 0.0 & $3.2 \pm 11.0$ \\
\hline $1 / 3$ medium & 86.8 & 2.9 & 8.8 & 1.5 & 0.0 & $4.7 \pm 13.1$ \\
\hline 1/3 upper & 100.0 & 0.0 & 0.0 & 0.0 & 0.0 & $0.0 \pm 0.0$ \\
\hline Maximum & 85.3 & 4.4 & 8.8 & 1.5 & 0.0 & $4.8 \pm 13.1$ \\
\hline
\end{tabular}

${ }^{\mathrm{a}}$ Corresponding to 67 patients; ${ }^{\mathrm{b}}$ mean \pm standard deviation of percentage of expressing cells. ${ }^{\mathrm{c}}$ The highest score out of the three thirds was assigned to each case.

Table IV. Percentage expression of substance $P$ and NK-1R in oral tumors $(n=83) .^{a}$

\begin{tabular}{|c|c|c|c|c|c|c|c|}
\hline & \multicolumn{6}{|c|}{ Expression (\%) } & \multirow[b]{2}{*}{ mean $\pm \mathrm{sd}^{\mathrm{b}}$} \\
\hline & $\mathrm{n}$ & $\begin{array}{c}\text { Negative } \\
(0 \%)\end{array}$ & $\begin{array}{c}+ \\
(1-25 \%)\end{array}$ & $\begin{array}{c}++ \\
(26-50 \%)\end{array}$ & $\begin{array}{c}+++ \\
(51-75 \%)\end{array}$ & $\begin{array}{c}++++ \\
(76-100 \%)\end{array}$ & \\
\hline \multicolumn{8}{|c|}{ Expression of SP } \\
\hline Nucleus & 65 & 61.5 & 15.4 & 7.7 & 9.2 & 6.2 & $16.2 \pm 27.0$ \\
\hline Cytoplasm & 78 & 19.2 & 16.7 & 14.1 & 25.6 & 24.4 & $45.1 \pm 33.4$ \\
\hline Membrane & 63 & 28.6 & 15.9 & 22.2 & 23.8 & 9.5 & $33.9 \pm 29.9$ \\
\hline \multicolumn{8}{|c|}{ Expression of NK-1R } \\
\hline Cytoplasm & 79 & 49.4 & 19.0 & 17.7 & 11.4 & 2.5 & $18.6 \pm 24.4$ \\
\hline Membrane & 79 & 86.1 & 6.3 & 5.1 & 1.3 & 1.3 & $4.7 \pm 14.6$ \\
\hline
\end{tabular}

${ }^{a}$ Corresponding to 67 patients; ${ }^{b}$ mean \pm standard deviation of percentage of expressing cells. 
Table V. Comparison of expression of SP and NK-1R in epithelium adjacent to oral tumors according to the presence of severe dysplasia/carcinoma in situ $(\mathrm{n}=83){ }^{\mathrm{a}}$

\begin{tabular}{|c|c|c|c|}
\hline & \multicolumn{2}{|c|}{ Severe dysplasia/carcinoma in situ $(\text { mean } \pm \mathrm{sd})^{\mathrm{b}}$} & \multirow[b]{2}{*}{ p-value } \\
\hline & No & Yes & \\
\hline Expression of SP & $52^{\mathrm{d}}$ & $16^{\mathrm{d}}$ & \\
\hline \multicolumn{4}{|l|}{ Nucleus } \\
\hline 1/3 lower & $6.1 \pm 16.9$ & $38.6 \pm 30.0$ & $<0.001$ \\
\hline $1 / 3$ medium & $8.3 \pm 19.0$ & $38.6 \pm 30.0$ & $<0.001$ \\
\hline 1/3 upper & $0.3 \pm 1.8$ & $12.6 \pm 23.5$ & 0.034 \\
\hline Maximum $^{\mathrm{e}}$ & $9.0 \pm 19.4$ & $38.6 \pm 30.0$ & $<0.001$ \\
\hline \multicolumn{4}{|l|}{ Cytoplasm } \\
\hline 1/3 lower & $21.4 \pm 29.6$ & $41.8 \pm 31.1$ & 0.023 \\
\hline $1 / 3$ medium & $20.4 \pm 29.7$ & $43.3 \pm 31.5$ & 0.011 \\
\hline $1 / 3$ upper & $0.0 \pm 0.0$ & $14.2 \pm 26.0$ & 0.028 \\
\hline Maximum & $22.6 \pm 30.0$ & $43.3 \pm 31.5$ & 0.021 \\
\hline \multicolumn{4}{|l|}{ Membrane } \\
\hline 1/3 lower & $25.3 \pm 29.2$ & $32.3 \pm 30.5$ & 0.414 \\
\hline $1 / 3$ medium & $29.9 \pm 27.7$ & $33.1 \pm 29.8$ & 0.703 \\
\hline $1 / 3$ upper & $2.4 \pm 12.2$ & $7.9 \pm 21.5$ & 0.326 \\
\hline Maximum & $31.1 \pm 27.8$ & $33.1 \pm 29.8$ & 0.812 \\
\hline Expression of NK-1R & 45 & 11 & \\
\hline \multicolumn{4}{|l|}{ Cytoplasm } \\
\hline 1/3 lower & $6.2 \pm 14.9$ & $5.7 \pm 19.0$ & 0.937 \\
\hline $1 / 3$ medium & $8.2 \pm 17.1$ & $10.4 \pm 21.0$ & 0.739 \\
\hline 1/3 upper & $0.3 \pm 1.9$ & $0.0 \pm 0.0$ & 0.323 \\
\hline Maximum & $8.2 \pm 17.1$ & $10.4 \pm 21.0$ & 0.739 \\
\hline \multicolumn{4}{|l|}{ Membrane } \\
\hline 1/3 lower & $3.9 \pm 13.1$ & $1.2 \pm 3.9$ & 0.248 \\
\hline $1 / 3$ medium & $5.6 \pm 14.9$ & $4.6 \pm 11.7$ & 0.811 \\
\hline 1/3 upper & $0.0 \pm 0.0$ & $0.0 \pm 0.0$ & - \\
\hline Maximum & $5.6 \pm 14.9$ & $4.6 \pm 11.7$ & 0.811 \\
\hline
\end{tabular}

${ }^{a}$ Corresponding to 67 patients; ${ }^{b}$ mean \pm standard deviation of percentage of expressing cells. ${ }^{c}$ SUDAAN DESCRIPT procedure, to correct for clustering (multiple oral cancers within patients). ${ }^{\mathrm{d}}$ The difference with the total of 83 tumors corresponds to missing cases for the

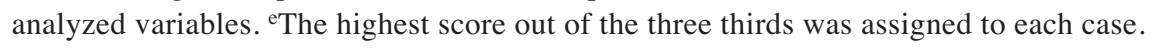

Table VI. Correlation of the expression of SP between adjacent epitheliuma and tumor according to the presence of severe dysplasia/carcinoma in situ $(\mathrm{n}=83) .^{\mathrm{b}}$

Severe dysplasia/carcinoma in situ

\begin{tabular}{|c|c|c|c|c|c|c|c|c|c|}
\hline & \multirow{2}{*}{\multicolumn{3}{|c|}{ All }} & \multirow{2}{*}{\multicolumn{3}{|c|}{ No }} & & & \\
\hline & & & & & & & \multicolumn{3}{|c|}{ Yes } \\
\hline & $\mathrm{n}^{\mathrm{c}}$ & $\mathrm{r}^{\mathrm{d}}$ & p-value & $\mathrm{n}$ & $\mathrm{r}$ & p-value & $\mathrm{n}$ & $\mathrm{r}$ & $\mathrm{p}$-value \\
\hline Nucleus & 55 & 0.71 & $<0.001$ & 42 & 0.49 & 0.002 & 13 & 0.71 & $<0.001$ \\
\hline Cytoplasm & 64 & 0.63 & $<0.001$ & 49 & 0.56 & $<0.001$ & 15 & 0.92 & $<0.001$ \\
\hline Membrane & 51 & 0.61 & $<0.001$ & 40 & 0.56 & $<0.001$ & 11 & 0.75 & $<0.001$ \\
\hline
\end{tabular}

${ }^{a}$ The highest score out of the three thirds (lower, medium, or upper) was assigned to each case. ${ }^{\mathrm{b}}$ Corresponding to 67 patients. ${ }^{\mathrm{c}}$ The difference with the total of 83 tumors corresponds to missing cases for epithelial and/or tumor expression. ${ }^{\mathrm{d}}$ Linear correlation; ${ }^{\mathrm{e}}$ calculated with the SUDAAN REGRESS procedure to correct for clustering (multiple oral cancers in patients). 
In conclusion, the role of SP in the malignant transformation of oral epithelium suggested by our results must be verified in wider studies. Research is also required into the pathogenic pathways by which substance $\mathrm{P}$ operates in order to develop novel approaches to prevent the malignant transformation of precancerous epithelium.

\section{References}

1. Choi S and Myers JN: Molecular pathogenesis of oral squamous cell carcinoma: implications for therapy. J Dent Res 87: 14-32, 2008.

2. Tabor MP, Brakenhoff RH, van Houten VM, et al: Persistence of genetically altered fields in head and neck cancer patients: biological and clinical implications. Clin Cancer Res 7: 1523-1532, 2001.

3. Califano J, van Der Riet P, Westra W, et al: Genetic progression model for head and neck cancer: implications for field cancerization. Cancer Res 56: 2488-2492, 1996.

4. Braakhuis B, Leemans C and Brakenhoff R: A genetic progression model of oral cancer: current evidence and clinical implications. J Oral Pathol Med 33: 317-322, 2004.

5. Kelloff GJ, Lippman SM, Dannenberg AJ, et al: Progress in chemoprevention drug development: the promise of molecular biomarkers for prevention of intraepithelial neoplasia and cancer. A plan to move forward. Clin Cancer Res 12: 3661-3697, 2006.

6. Esteban F, Muñoz M, Gonzalez-moles MA and Rosso M: A role for substance $\mathrm{P}$ in cancer promotion and progression: a mechanism to counteract intracellular death signals following oncogen activation or DNA damage. Cancer Metastasis Rev 25: 137-145, 2006

7. Quartara L and Maggi CA: The tachykinin NK1R receptor Part II: distribution and pathophysiological roles. Neuropeptides 32: 1-49, 1998

8. Kramer MS, Cutler N, Feighner J, et al: Distinct mechanism for antidepressant activity by blockade of central substance P receptors. Science 281: 1640-1645, 1998.

9. Harrison S and Geppetti P: Substance P. Int J Biochem Cell Biol 33: 555-576, 2001

10. Bang R, Sass G, Kiemer AK, Vollmar AM, Neuhuber WL and Tiegs G: Neurokinin-1 receptor antagonists CP-96,345 and L-733,060 protect mice from cytokine-mediated liver injury. J Pharmacol Exp Ther 305: 31-39, 2003.

11. Muñoz M, Pérez A, Coveñas R, Rosso M and Castro E: Antitumoral action of L-733,060 on neuroblastoma and glioma cell lines. Arch Ital Biol 142: 105-112, 2004.
12. Muñoz M, Pérez A, Rosso M, Zamarriego C and Rosso R: Antitumoral action of NK1R receptor antagonist L-733,060 on human melanoma cell lines. Melanoma Res 14: 183-188, 2004.

13. Muñoz M, Rosso M, Pérez A, Coveñas R, Rosso R, Zamarriego C and Piruat JI: The NK1R receptor is involved in the antitumoral action of L-733,060 and in the mitogenic action of substance $\mathrm{P}$ on neuroblastoma and glioma cell lines. Neuropeptides 39: 427-432, 2005

14. Muñoz M, Rosso M, Pérez A, Coveñas R, Rosso R and Zamarriego C: Antitumoural action of the neurokinin-1-receptor antagonist L-733,060 and mitogenic action of substance $\mathrm{P}$ on human retinoblastoma cell lines. Invest Ophthalmol Vis Sci 46: 2567-2570, 2005

15. Muñoz M, Rosso M, Aguilar FJ, Gonzalez-Moles MA, Redondo $\mathrm{M}$ and Esteban F: NK-1 receptors antagonists induce apoptosis and counteract substance-P related mitogenesis in human laryngeal cancer cell line Hep-2. Invest New Drugs 26: 111-118, 2008 .

16. González-Moles MA, Mosqueda-Taylor A, Esteban F Gil-Montoya JA, Díaz-Franco MA, Delgado M and Muñoz M: Cell proliferation associated with actions of the Substance P/NK-1 receptor complex in keratocystic odontogenic tumours. Oral Oncol 44: 1127-1133, 2008.

17. González-Moles M, Esteban F, Ruiz-Ávila I, Gil-Montoya JA, Brener S, Bascones-Martínez A and Muñoz M: A role for substance P/NK-1 receptor complex in cell proliferation and apoptosis in oral lichen planus. Oral Dis 15: 162-169, 2009.

18. Barnes L, Eveson JW, Reichart PA and Sidransky D: World Health Organization classification of tumours. Pathology and genetics. Head and neck tumours. World Health Organization, 2005.

19. De Felipe C, Herrero JF, O'Brien JA, et al: Altered nociception, analgesia and aggression in mice lacking the receptor for substance P. Nature 392: 394-397, 1998.

20. Janes SM, Lowell S and Hutter C: Epidermal stem cells. J Pathol 197: 479-491, 2002.

21. Zhu AJ and Watt FM: Beta-catenin signalling modulates proliferative potential of human epidermal keratinocytes independently of intercellular adhesion. Development 126: 2285-2298, 1999.

22. Pandi-Perumal SR, Trakht I, Srinivasan V, Spence DW, Maestroni GJ, Zisapel N and Cardinali DP: Physiological effects of melatonin: role of melatonin receptors and signal transduction pathways. Prog Neurobiol 85: 335-353, 2008.

23. Mignogna MD, Fedele S, Lo Russo L, Lo Muzio L and Bucci E: Immune activation and chronic inflammation as the cause of malignancy in oral lichen planus: is there any evidence? Oral Oncol 40: 120-130, 2004 